\title{
Article
}

\section{Identical non-identical twins and non- identical identical twins}

\author{
Vadgama, Nirmal, Nirmalananthan, Niranjanan, Sadiq, Mustafa, \\ Hardy, John and Nasir, Jamal \\ Available at https://clok.uclan.ac.uk/18276/ \\ Vadgama, Nirmal, Nirmalananthan, Niranjanan, Sadiq, Mustafa, Hardy, John \\ and Nasir, Jamal (2015) Identical non-identical twins and non-identical \\ identical twins. BMJ, 351 . h6589. ISSN 0959-8138
}

It is advisable to refer to the publisher's version if you intend to cite from the work. http://dx.doi.org/10.1136/bmj.h6589

For more information about UCLan's research in this area go to http://www.uclan.ac.uk/researchgroups/ and search for <name of research Group>.

For information about Research generally at UCLan please go to http://www.uclan.ac.uk/research/

All outputs in CLoK are protected by Intellectual Property Rights law, including Copyright law. Copyright, IPR and Moral Rights for the works on this site are retained by the individual authors and/or other copyright owners. Terms and conditions for use of this material are defined in the policies page.

\section{CLoK}

Central Lancashire online Knowledge www.clok.uclan.ac.uk

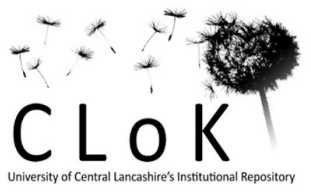




\title{
Identical non-identical twins and non-identical identical twins
}

\author{
Nirmal Vadgama PhD student, Institute of Neurology, University College London, London WC1N \\ 3BG, UK, Niranjanan Nirmalananthan consultant neurologist, Neurosciences, St George's University \\ Hospitals NHS Foundation Trust, London, Mustafa Sadiq consultant obstetrician and gynaecologist, \\ Warrington and Halton Hospitals NHS Foundation Trust, Warrington, UK, John Hardy professor of \\ neuroscience, Department of Molecular Neuroscience, University College London, Jamal Nasir \\ multiprofessional facilitator, Education Department, St George's University Hospitals NHS Foundation \\ Trust
}

In recruiting monozygotic (MZ) twins for our ongoing research into de novo mutations in phenotypically discordant $\mathrm{MZ}$ twins, we have come across an increasing number of participants who have been told they are dizygotic (DZ) but have almost identical traits and physical features, or MZ but present more like fraternal siblings. Current practice guidelines for classifying twins as either MZ or DZ, which are still largely based on chorionicity (the notion of whether or not the twins shared a placenta) and physical similarity, are prone to error. ${ }^{1}$ A common error in zygosity assignment is the supposition that like-sexed twins are $\mathrm{DZ}$ if they were determined to be dichorionic at birth. Up to $25 \%$ of all like-sexed twin pairs classified as DZ and $7 \%$ classified as MZ by chorionicity turn out to be misclassifications, according to results of DNA based gold standard methods. ${ }^{23}$ Furthermore, rare cases of monochorionic DZ twins have been reported. ${ }^{4}$

We have noted how important it is for twins and their families to establish whether or not they are truly genetically identical, and we believe any level of uncertainty can have a lasting psychological effect on them. There are also important medical reasons to know correct MZ or DZ classification, as morbidities are generally shared more among MZ than DZ twins-not to mention the particular importance of genetic compatibility when considering organ transplantation. Moreover, from a social perspective, since it is considered unethical to separate twins for adoption without their acknowledgment or against their will, one could argue that denying twins access to an intrinsic biological fact of their existence, by reason of its presumed triviality or cost, is also unethical.

It would be simple, cheap, and quick to carry out genetic testing using placental tissue or even buccal swabs in all like-sexed twins at the time of birth. If these opportunities are not met, twins and their families may draw false conclusions or may have to resort to other methods of zygosity testing later in life. With roughly 12000 like-sexed multiple births annually in the United Kingdom, our estimated annual cost to the NHS of less than $£ 2 \mathrm{~m}(€ 2.8 \mathrm{~m}$; $\$ 3 \mathrm{~m})$ would be money well spent.

Competing interests: We have read and understood BMJ's policy on declaration of interests and have no relevant interests to declare.

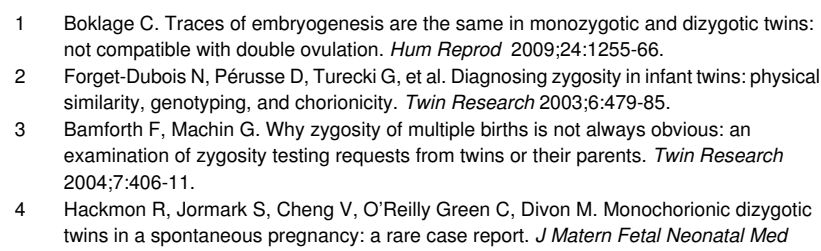

Boklage $\mathrm{C}$. Traces of embryogenesis are the same in monozygotic and dizygotic twins: not compatible with double ovulation. Hum Reprod 2009;24:1255-66.

2 Forget-Dubois N, Pérusse D, Turecki G, et al. Diagnosing zygosity in infant twins: physical similarity, genotyping, and chorionicity. Twin Research 2003;6:479-85.

3 Bamforth F, Machin G. Why zygosity of multiple births is not always obvious: an examination of zygosity testing requests from twins or their parents. Twin Research 2004;7:406-11.

4 Hackmon R, Jormark S, Cheng V, O'Reilly Green C, Divon M. Monochorionic dizygotic twins in a spontaneous pregnancy: a rare case report. $J$ Matern Fetal Neonatal Med 2009;22:708-10. 